\title{
Geographic variation in Crowea exalata (Rutaceae) and the recognition of two new subspecies
}

\author{
Wayne A. Gebert ${ }^{1}$ and Marco F. Duretto ${ }^{2}$ \\ ${ }^{1}$ National Herbarium of Victoria, Royal Botanic Gardens Melbourne, Private Bag 2000, South \\ Yarra, VIC, 3141, Australia \\ ${ }^{2}$ Tasmanian Herbarium, Tasmanian Museum and Art Gallery, Private Bag 4, Hobart, TAS, 7001, \\ Australia \\ Author for correspondence: Wayne.Gebert@rbg.vic.gov.au
}

\begin{abstract}
Crowea exalata F.Muell. was sampled throughout its morphological and geographical range to test the validity of the current circumscription of the species and subspecies. Through numerical analysis of morphological and chemical (leaf flavonoids and volatile oils) data four taxa are recognised, subsp. exalata, subsp. revoluta Paul G.Wilson, subsp. magnifolia Gebert subsp. nov. and subsp. obcordata Gebert subsp. nov. Descriptions and a key to all taxa are provided.
\end{abstract}

\section{Introduction}

Crowea Sm. (Rutaceae) is an Australian genus of three species that was first described by J.E. Smith and named in honour of James Crowe esq. F.L.S. (Smith 1798, 1808). Smith, however, was not one to give specific epithets to species of monotypic genera, and in the case of Crowea this was done by Andrews (1800) when he described C. saligna Andrews (see Wilson 1970). Members of Crowea are multi-stemmed, erect, evergreen, woody perennials to $2 \mathrm{~m}$ tall with white to rose pink, solitary, axillary flowers.

Probably the closest relative to Crowea is Eriostemon Sm. (Bayly et al. 1998; Wilson 1998). Eriostemon contains two species, E. australasius Pers. and E. banksii A.Cunn. ex Endl. Eriostemon australasius is often found in sympatry with C. saligna and C. exalata F.Muell. from which it can be distinguished on the basis of floral morphology; Crowea has pilose anthers and pedicels 1-4 mm long, while Eriostemon has glabrous anthers and pedicels 4-12 mm long (Bayly et al. 1998).

In the past, the relationship between Crowea and Eriostemon has not been clearly

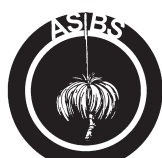

Paper from the Australian Systematic Botany Society Conference held in Darwin, September 2007 
defined. Mueller (1862) relegated Crowea to synonymy under Eriostemon and described E. crowei F.Muell. (based on C. saligna). Bentham (1863) did not accept Mueller's classification and recognised Crowea as a taxon distinct from Eriostemon and Phebalium with the species exalata, saligna, angustifolia and dentata $(=C$. angustifolia). Baillon (1873) placed both Eriostemon and Phebalium Vent. in Crowea as sections and coined the name Eucrowea, which included taxa now accepted as members of Crowea. Mueller's classification was followed by Moore and Betche (1893), Maiden and Betche (1916) and Beadle et al. (1962) who included the varieties crowei $(=C$. saligna) and exalata (F.Muell.) Maiden et Betche $(=C$. exalata $)$ but most workers in the intervening period followed Bentham.

Crowea was last revised by Wilson (1997) who recognised three species, C. saligna, C. angustifolia and $C$. exalata. Crowea saligna is restricted to the Hawkesbury sandstone regions of Sydney, and $C$. angustifolia is restricted to the south-western corner of Western Australia (Wilson 1970). Crowea exalata has the largest geographical and ecological distribution of all the species in the genus being found from southern Queensland to central Victoria. It is found in coastal, inland and montane areas, on rocky, clayey or sandy, well drained, moist soils (Fig. 1).

Crowea exalata, as currently circumscribed, has two subspecies, C. exalata subsp. exalata and C. exalata subsp. revoluta Paul G.Wilson. These taxa are separated on leaf width and length, margin curvature and flower size, with subsp. revoluta being the morphologically smaller of the two subspecies (Wilson 1997, Duretto 1999).

The use of chemical characters is now well established in many areas of systematics, including taxonomy (McClure \& Alston 1966, Conn \& Whiffin 1987, Southwell \& Brophy 1992, Raleigh et al. 1994, Duewell 1997, Bayly et al. 1998), studies of geographic variation (Banks \& Hillis 1969, Brooker \& Lassak 1981, Whiffin \& Ladiges 1992, Middleton et al. 1996, Wright \& Ladiges 1997), hybridisation (Whiffin 1977, 1981; Leach \& Whiffin 1978) and introgression (Flake et al. 1978). In systematic studies, volatile oils have proved useful in the area of infraspecific variation and species relationships, whereas phenolics, such as flavonoids, usually prove more useful at the species or genus level (Harborne \& Turner 1984).

The use of volatile oils in taxonomy has a major advantage in that they provide large numbers of characters with no bias, are fairly accurate and are quantifiable (Whiffin 1977, 1982b; Whiffin \& Hyland 1989; Whiffin \& Ladiges 1992). Volatile oils have also been shown to be under strict genetic control (Hanover 1966, von Rudloff 1972). Even though environmental factors are known to affect the quantity of oil produced, the composition of the oil, expressed as the percentage of the total oil accounted for by each compound, does not seem to vary significantly on a seasonal basis (von Rudloff 1972; Whiffin 1982a, 1982b; Leach \& Whiffin 1989). Ontogenetic variation is known to affect the composition of the oil, with a significant difference between young and mature leaves (von Rudloff 1972, Whiffin 1982b, Whiffin \& Hyland 1989, Leach \& Whiffin 1989). For analytical purposes, variation due to ontogenetic and environmental factors can be eliminated or reduced by utilising mature leaves only (Whiffin 1982b, Whiffin \& Hyland 1989, Leach \& Whiffin 1989).

The chemistry of Crowea has received little attention in the past. The essential oils from C. saligna were first described by Penfold and Morrison (1922, cited as E. crowei), while more recently a study of the major essential oil compounds of Crowea taxa has been published (Brophy et al. 1997). Brophy et al. (1997) described five chemotypes, 


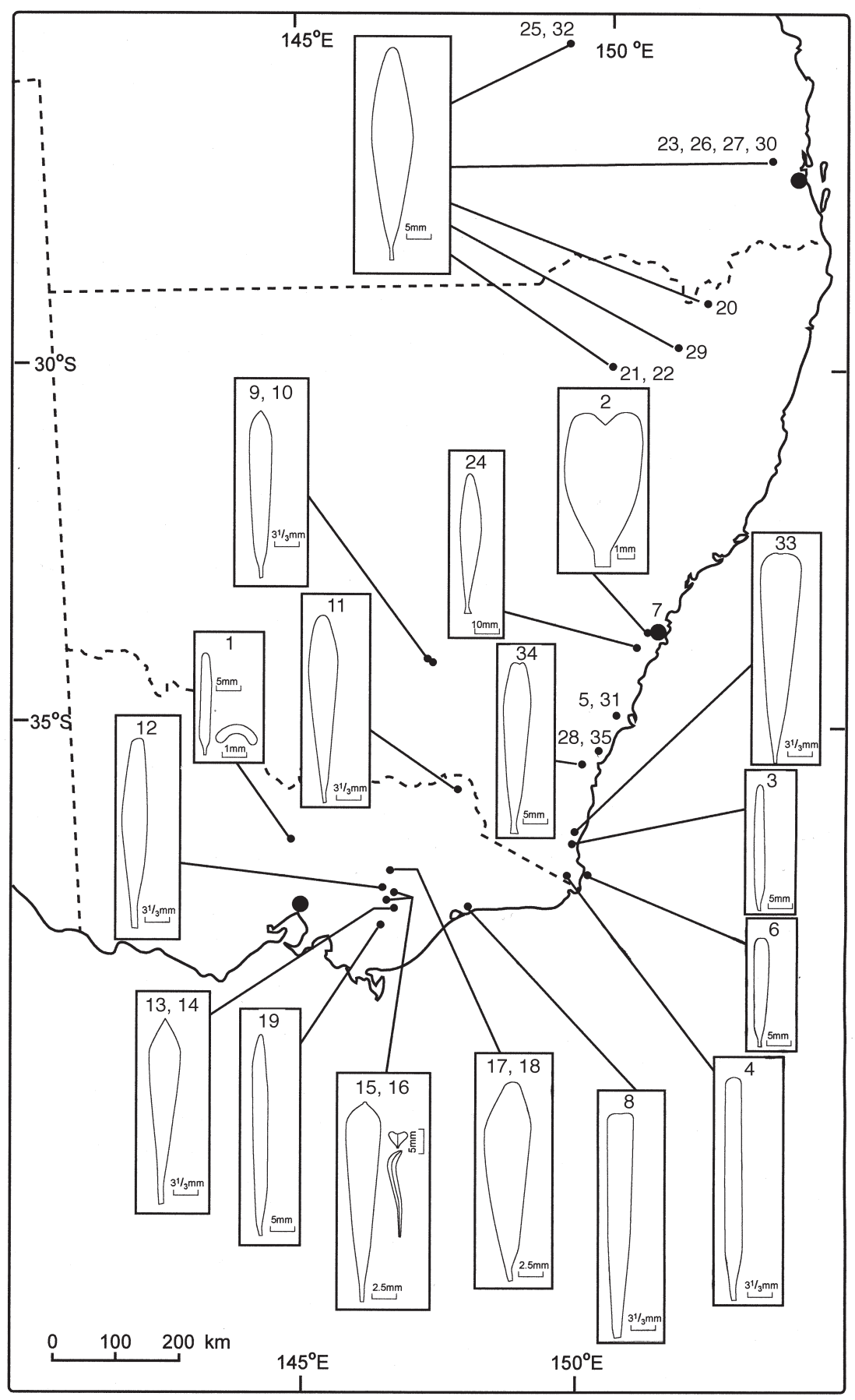

Fig. 1. Locations of populations of Crowea exalata sampled for study and illustrations showing leaf variation. Cross section of leaf shown for populations 1 and 15/16, and side view of leaf shown for population 15/16. See Table 1 for collection details of samples 1-35. 
but the sampling regime did not cover the full geographic range of the three species, contributing to the knowledge of the oil composition of Crowea but having little taxonomic value as their study did not attempt to correlate oil composition with morphology. In the related genus Eriostemon, the rationale for reinstating E. banksii to species level was based in part on volatile oils data. The use of volatile oils by Brophy et al. (1997) and Bayly et al. (1998), and a review by Ghisalberti (1997) on the phytochemistry of Boronia Sm., Eriostemon and Phebalium species, reinforces the value of volatile oils as a character in this study.

Phenolics, like volatile oils, are under strict genetic control (Harborne \& Turner 1984) and have been used in many studies because they are very stable and show very little ontogenetic or seasonal variation (Leach \& Whiffin 1989). Unlike volatile oils, flavonoid analyses are usually qualitative, in terms of presence or absence on twodimensional paper chromatography: therefore any seasonal or ontogenetic changes in the quantity of the compounds are hard to detect (Leach \& Whiffin 1989). Prior to this study phenolic compounds have not been used as characters in the classification of Crowea.

In this study, the morphological variation within C. exalata was examined. The current literature suggests that subsp. revoluta shows the least amount of variation within this species in terms of flower and leaf size and shape, whilst subsp. exalata exhibits considerable variation in leaf size and shape across its geographic range (Wilson 1970, 1997; Duretto 1999). Wilson (1997) indicated that subsp. revoluta 'appeared' to grade with subsp. exalata. In addition to morphological analyses, the degree of chemical variation within $C$. exalata was assessed through investigation of the composition of the flavonoids and volatile oils.

\section{Materials and Methods}

Sampling: herbarium specimens of C. exalata were obtained from BRI, CANB, MEL, NE and NSW. Herbarium abbreviations follow Holmgren et al. (1990). In addition, 10 plants from each of 21 populations were sampled throughout the morphological and distributional range of the species (Fig. 1; Table 1). Leaves were collected from each plant and kept cool in polyethylene bags until processed for use in morphological and chemical analysis. Vouchers for all material are lodged at MEL with duplicates, where possible, distributed to CANB, LTB, NE and NSW.

Morphological Characters: ten leaves from each of the five plants per field population and 10 leaves from each of the 12 herbarium specimens (Table 1) were scanned using 'Morphosys' version 1.26 (Meacham \& Duncan 1989). Four reference points were added to the scanned images. These points represented: 1-leaf base, 2 and 4-either side of the leaf at the widest point, and 3-leaf tip. An additional point, point 5, was automatically calculated as midpoint between 2 and 4 which represented the midpoint of the leaf where the leaf is widest. Seven leaf morphological characters were derived via 'Morphosys' (Table 2). Seven floral characters were measured for all taxa where material was available (using five replicates for each population). The floral characters were measured from field collections kept in 80\% aqueous ethanol (80:20 - ethanol:distilled water) and from herbarium specimens. Due to the haphazard arrangement of the flowers on the herbarium specimens, it was not always possible to obtain five replicates 
Table 1. Populations sampled for analyses.

\begin{tabular}{|c|c|c|c|}
\hline $\begin{array}{l}\text { Pop'n or } \\
\text { spec No. }\end{array}$ & Collector No. & Herbarium & $\begin{array}{l}\text { Location/ } \\
\text { Sheet No. }\end{array}$ \\
\hline 1 & Gebert 1-10 & LTB \& MEL & Whipstick SF, Vic., $36^{\circ} 41^{\prime} S 144^{\circ} 17 \mathrm{E}$ \\
\hline 2 & Olson 3997 & NSW 257535 & Budthingeroo Creek, NSW, 33⒌ $55^{\prime} \mathrm{S} 150^{\circ} 01^{\prime} \mathrm{E}$ \\
\hline 3 & Gebert 11-20 & LTB, MEL \& NSW & Bournda Trig, NSW, $36^{\circ} 49^{\prime} \mathrm{S} 149^{\circ} 55^{\prime} \mathrm{E}$ \\
\hline 4 & Gebert 128-137 & LTB \& MEL & Imlay Ck, NSW, $37^{\circ} 16^{\prime} \mathrm{S} 149^{\circ} 40^{\prime} \mathrm{E}$ \\
\hline 5 & Gebert 127 & MEL \& NSW & Yalwal, NSW, $34^{\circ} 55^{\prime} \mathrm{S} 150^{\circ} 24^{\prime} \mathrm{E}$ \\
\hline 6 & Gebert 21-30 & LTB \& MEL & 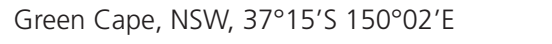 \\
\hline 7 & Constable s.n. & NSW 42706 & Glenbrook, NSW, $33^{\circ} 46^{\prime} \mathrm{S} 150^{\circ} 37^{\prime} \mathrm{E}$ \\
\hline 8 & Gebert 31-33 & MEL & Nowa Nowa, Vic., $37^{\circ} 44^{\prime} S 148^{\circ} 05^{\prime} E$ \\
\hline 9 & Gebert 70-79 & LTB \& MEL & Buddigower SF, NSW, $34^{\circ} 04^{\prime} \mathrm{S} 147^{\circ} 06^{\prime} \mathrm{E}$ \\
\hline 10 & Gebert 80-89 & LTB, MEL \& NSW & Buggajool SF, NSW, $34^{\circ} 10^{\prime} S 147^{\circ} 12^{\prime} E$ \\
\hline 11 & Gebert 90-99 & LTB \& MEL & Pine Mtn, Vic., $36^{\circ} 01^{\prime} \mathrm{S} 147^{\circ} 50^{\prime} \mathrm{E}$ \\
\hline 12 & Gebert 178, 179 & LTB, MEL \& NSW & Macalister R., Vic., 372ㄱ'S $146^{\circ} 33^{\prime} E$ \\
\hline 13,14 & Gebert 148-167 & LTB \& MEL & Dolobrook Track, Vic., $37^{\circ} 44^{\prime} \mathrm{S} 146^{\circ} 45^{\prime} \mathrm{E}$ \\
\hline 15 & Gebert 168-177 & LTB \& MEL & Wellington R., Vic., $37^{\circ} 31^{\prime} \mathrm{S} 146^{\circ} 39^{\prime} \mathrm{E}$ \\
\hline 16 & Gebert 180-189 & MEL \& NSW & Dinner Ck Gorge, Vic., $37^{\circ} 31^{\prime} \mathrm{S} 146^{\circ} 40^{\prime} \mathrm{E}$ \\
\hline 17 & Muir 735 & MEL 4511 & Dandongadale Falls, Vic., $37^{\circ} 03^{\prime} S 146^{\circ} 37^{\prime} \mathrm{E}$ \\
\hline 18 & Gebert 190-199 & LTB \& MEL & Mt Howitt, Vic., $37^{\circ} 10^{\prime} \mathrm{S} 146^{\circ} 40^{\prime} \mathrm{E}$ \\
\hline 19 & Gebert 117-126 & LTB \& MEL & Thompson R., Vic., $38^{\circ} 00^{\prime} \mathrm{S} 146^{\circ} 28^{\prime} \mathrm{E}$ \\
\hline 20 & Gebert 34-43 & $\begin{array}{l}\text { LTB, MEL, NSW } \\
\text { UNE }\end{array}$ & Emmaville, NSW, $29^{\circ} 15^{\prime} \mathrm{S} 151^{\circ} 34^{\prime} \mathrm{E}$ \\
\hline 21 & Gebert 58-67 & MEL & Waa Gorge, NSW, $30^{\circ} 04^{\prime}$ S $150^{\circ} 06^{\prime} E$ \\
\hline 22 & Gebert 48-57 & $\begin{array}{l}\text { LTB, MEL, NSW } \\
\text { UNE }\end{array}$ & Waa Gorge, NSW, $30^{\circ} 04^{\prime} \mathrm{S} 150^{\circ} 06^{\prime} \mathrm{E}$ \\
\hline 23 & Forster PIF16398 & BRI AQ634982 & Mt Byron, Qld, $27^{\circ} 06^{\prime} \mathrm{S} 152^{\circ} 40^{\prime} \mathrm{E}$ \\
\hline 24 & Gebert 100-109 & LTB \& MEL & Tahmoor, NSW, $34^{\circ} 15^{\prime} \mathrm{S} 150^{\circ} 35^{\prime} \mathrm{E}$ \\
\hline 25 & Forster PIF17742 & MEL 278735 & Expedition NP, Qld, $25^{\circ} 20^{\prime} \mathrm{S} 149^{\circ} 11^{\prime} \mathrm{E}$ \\
\hline 26 & Young 800 & BRI AQ394796 & Mt Byron, Qld, $27^{\circ} 00^{\prime} \mathrm{S} 152^{\circ} 40^{\prime} \mathrm{E}$ \\
\hline 27 & Grimshaw G601 & BRI AQ600852 & 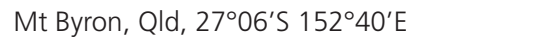 \\
\hline 28 & Shoobridge s.n. & CANB 023972 & Mogo SF, NSW, $35^{\circ} 47^{\prime} \mathrm{S} 150^{\circ} 04^{\prime} \mathrm{E}$ \\
\hline 29 & Gebert 46 & MEL & Howell, NSW, $29^{\circ} 57^{\prime} \mathrm{S} 151^{\circ} 02^{\prime} \mathrm{E}$ \\
\hline 30 & Forster PIF17392 & BRI AQ638096 & Mt Mee SF, Qld, $27^{\circ} 07^{\prime} \mathrm{S} 152^{\circ} 41^{\prime} \mathrm{E}$ \\
\hline 31 & Blaxell 1605 & NSW 299859 & Yalwal, NSW, 345 $55^{\prime}$ S $150^{\circ} 22^{\prime} \mathrm{E}$ \\
\hline 32 & Forster PIF17759 & BRI AQ638862 & Expedition Range, Qld, $25^{\circ} 20^{\prime} \mathrm{S} 149^{\circ} 11^{\prime} \mathrm{E}$ \\
\hline 33 & Gebert 110-116 & LTB \& MEL & Dr George Mtn, NSW, $36^{\circ} 40^{\prime} \mathrm{S} 149^{\circ} 54^{\prime} \mathrm{E}$ \\
\hline 34 & Gebert 138-147 & LTB \& MEL & Coondella Trig., NSW, $35^{\circ} 56^{\prime} \mathrm{S} 149^{\circ} 54^{\prime} \mathrm{E}$ \\
\hline 35 & Shoobridge s.n. & CANB 023969 & Mogo SF, NSW, $35^{\circ} 47^{\prime} \mathrm{S} 150^{\circ} 04^{\prime} \mathrm{E}$ \\
\hline
\end{tabular}


Table 2. Morphological characters used in the phenetic analysis.

1. Leaf length $(\mathrm{mm})$

2. Leaf width $(\mathrm{mm})$

3. Distance to widest point from the base $(\mathrm{mm})$

4. Distance to widest point from the top $(\mathrm{mm})$

5. Distance to widest point from the base : Leaf length

6. Perimeter of leaf $(\mathrm{mm})$

7. Area of leaf $\left(\mathrm{mm}^{2}\right)$

8. Petal length $(\mathrm{mm})$

9. Petal width $(\mathrm{mm})$

10. Petal width : Petal length

11. Pedicel length $(\mathrm{mm})$

12. Antesepalous stamen length ( $\mathrm{mm}$ )

13. Antepetalous stamen length ( $\mathrm{mm})$

14. Anther ratio

per specimen. Characters scored for the morphological analysis are listed in Table 2. Characters used were shown to be of use in delimiting taxa in other studies (eg. Wilson 1997) as well as from preliminary surveys.

Flavonoids: leaf material from five plants from each population was collected and analysed for flavonoid constituents. Leaves were air-dried for three to five days, then ground in a Waring blender and placed in air-tight glass jars until needed. Flavonoid extraction followed the procedures outlined in Mabry et al. (1970) and Markham (1982). Approximately $7 \mathrm{~g}$ of leaf material from each plant was placed in a $30 \mathrm{ml}$ glass vial and covered with $80 \%$ aqueous methanol (80:20 - methanol:distilled water) and left to soak for 24 hours, being agitated once during this period. Approximately $335 \mu \mathrm{l}$ of extract was applied to the chromatography sheet (Whatman $3 \mathrm{MM}$ chr $46 \times 57 \mathrm{~cm}$ ) over five applications, covering a circular area no greater than $3 \mathrm{~cm}$ diameter.

Two-dimensional paper chromatography was then carried out for each sample. The solvent used in the first dimension was a solution of tertiary butanol : glacial acetic acid : distilled water $(3: 1: 1 \mathrm{v} / \mathrm{v})$. The second dimension, which ran at 90 degrees to the first, utilised 15\% aqueous Acetic Acid (15:85 - Acetic Acid:distilled water). All sheets were viewed over UV light $(360 \mathrm{~nm})$ in both the absence and presence of ammonia vapour. A spot on two different sheets was considered the same when colour changes and $R_{f}$ values were similar. All compounds were arbitrarily assigned numbers as they were recognised. Compounds were scored as present or absent. No attempt was made to identify the compounds due to time constraints.

Volatile oils: leaf material was collected from five plants per population, where available, and the oil was extracted following the methodology of Newnham et al. (1986), Kottek et al. (1990), Whiffin and Bouchier (1992) and Whiffin and Ladiges (1992). The leaves were steam distilled in an all-glass apparatus to yield an oil-water mixture. The oil was separated from the water by mixing the oil-water mixture with twice distilled Freon 11 (trichlorofluoromethane, b.p. $23.7^{\circ} \mathrm{C}$ ) in a separating funnel and allowing it to stand for two hours. The Freon-oil mixture was then decanted from the funnel, excess water was 
removed by adding anhydrous sodium sulphate and the sodium sulphate was removed by filtration, leaving an anhydrous mixture. The mixture was collected and distilled to remove most of the Freon with any excess being removed by applying high purity nitrogen over the surface of the oil. The capped vials of oil were stored at $-20^{\circ} \mathrm{C}$.

The oil samples were analysed using a Perkin-Elmer 8310 gas chromatograph with a $25 \mathrm{~m} \times 0.23 \mathrm{~mm}$ fused silica column coated with BP225 (bonded OV101) and fitted with a flame ionisation detector. For each sample, a $0.2 \mu \mathrm{l}$ sub-sample was injected, with the split ratio set to $1: 100$. The gas chromatograph was temperature-programmed from $50-180^{\circ} \mathrm{C}$ at an increase of $2^{\circ} \mathrm{C}$ per minute for 65 minutes. The injection temperature was $250^{\circ} \mathrm{C}$ and the detector temperature was $270^{\circ} \mathrm{C}$.

A composite sample was also made up, consisting of a small sub-sample of oil from one plant per population. The composite was run every day to check for any changes in the gas chromatograph running conditions. One chromatograph obtained from the composite runs was used as the standard for chromatograms to be checked against. The peaks on the composite chromatogram were numbered consecutively from the beginning. Any peaks which were found on a sample chromatogram but not on the composite chromatogram were marked on the composite chromatogram and given a letter in the order in which they were found.

Tentative identification of the major compounds was attempted by comparing results herein with those of Brophy et al. (1997). Not all major compounds found in this study were able to be tentatively identified by comparison with Brophy et al. (1997) as some of the populations sampled in this study were not sampled by them.

Numerical analysis: each data set (available as PDFs from http://plantnet.rbgsyd.nsw. gov.au/Telopea); also given in Gebert 1999) was subjected to numerical analysis using PATN (Belbin 1987). For the morphological data set ratios (characters 4, 10, 14) were included as untransformed or as log-transformed data in different analyses. The ratios were removed from a third analysis. All averaged data were range-standardised, except for the volatile oil data as this would emphasise compounds of small quantities and bias the analysis (Whiffin 1982a, 1982b). Manhattan Metric (MM) distance matrices were calculated for all data sets as the appropriate similarity measure for continuous variables (Pimentel 1981, Belbin 1987). The resulting distance matrix was subjected to cluster analysis using unweighted pair-group method using arithmetic averages (UPGMA) and weighted pair-group method using arithmetic averages (WPGMA) as the fusion criteria to produce hierarchical dendrograms. Both cluster analysis strategies were utilised because UPGMA, where all OTU's have similar weight, is thought to be more accurate in the portrayal of relationships (Sneath \& Sokal 1973), and WPGMA is useful when the groups of interest are of dissimilar size. Larger groups tend to dominate the analysis in UPGMA and so smaller groups can become distorted (T.Whiffin pers. comm.; M.Duretto unpub. data; cited in Duretto \& Ladiges 1997). Principle coordinates analysis (PCoA) and Semi-Strong Hybrid Multidimensional Scaling (SSHMDA), with cut-off values of 0.9 and 0.1 , was carried out for all data sets. 


\section{Results}

PCoA and SSH-MDA produced virtually the same results and only PCoA is discussed further below. Likewise, the three strategies utilized on the ratio data in the morphological data, viz. untransformed, log-transformed or deleted, produced virtually the same results and only the results using the untransformed ratios is presented below.

Plant Morphology: analysis of the leaf and floral morphology data clearly shows five distinct groups (M1-M5) in the UPGMA dendrogram (Fig. 2) and the WPGMA (not shown) and, though not as clearly, in the ordination (Fig. 3).

Group M1 contains population 1 from the Victorian Midlands. Group M2 consists of populations 3-19, which range from the Central Coast of New South Wales to Eastern Victoria. Group M3 contains population 2 from the Central Tablelands of New South Wales. Group M4 contains populations 20-34, which range from the South Coast of New South Wales to south-eastern Queensland, and Group M5 contains population 35 from the South Coast of New South Wales.

Flavonoids: a total of 39 phenolic compounds were found in the 18 field populations of C. exalata sampled after chromatographic separation. Of these 39 compounds, seven $(1,13,14,21,22,25$, and 31$)$ are common in all populations, four $(37,38,39$, and 40$)$ were restricted to population 1, and compounds $12,18,20,29$, and 35 were restricted to populations 13 and $14,4,18,3$ and 6 respectively.

In the analysis three major groups (F1-F3) were recognised in the UPGMA (Fig. 4), WPGMA (not shown) and the ordination (Fig. 5). Group F1 is quite separate from Groups F2 and F3 and contains population 1 from the Victorian Midlands. Group F2 contains 13 populations ranging from the North Western Slopes of New South Wales south to the Snowfields of Victoria. Group F3 contains populations 19 and 15 from the Eastern Highlands of Victoria and population 34 from the South Coast of New South Wales.

Volatile Oils: a total of 231 volatile oil compounds were identified by gas chromatographic separation. Table 3 shows 5 major compounds and percent composition of each. These compounds are tentatively identified based on Brophy et al. (1997).

In the WPGMA (Fig. 6) and UPGMA (not shown) three major groups (V1-V3) are recognised and can be further divided into subgroups. Group V1 contains three subgroups; Group V1.1 contains three individuals from population 10, three individuals from population 15, and population 24; Group V1.2 contains population 19 and the remaining individuals from population 15; Group V1.3 contains a very tight cluster of individuals from population 22. Based on tentative identification Group V1 was found to contain high amounts of asaricin, except for population 19, which had low levels of all compounds (Table 3 ).

Group V2 contained three subgroups. Group V2.1 is made up of the remaining two individuals from population 10 and one individual from population 13; Group V2.2 contains populations 11,14, 20 and the remaining individuals from population 13; and Group V2.3 contains population 1. Group V2 was found to have high amounts of (E)-carpacin, except for population 1 which had low amounts of (E)-carpacin and higher amounts of asaricin. Population 20 also contained high amounts of (E)-methyl isoeugenol (Table 3). 


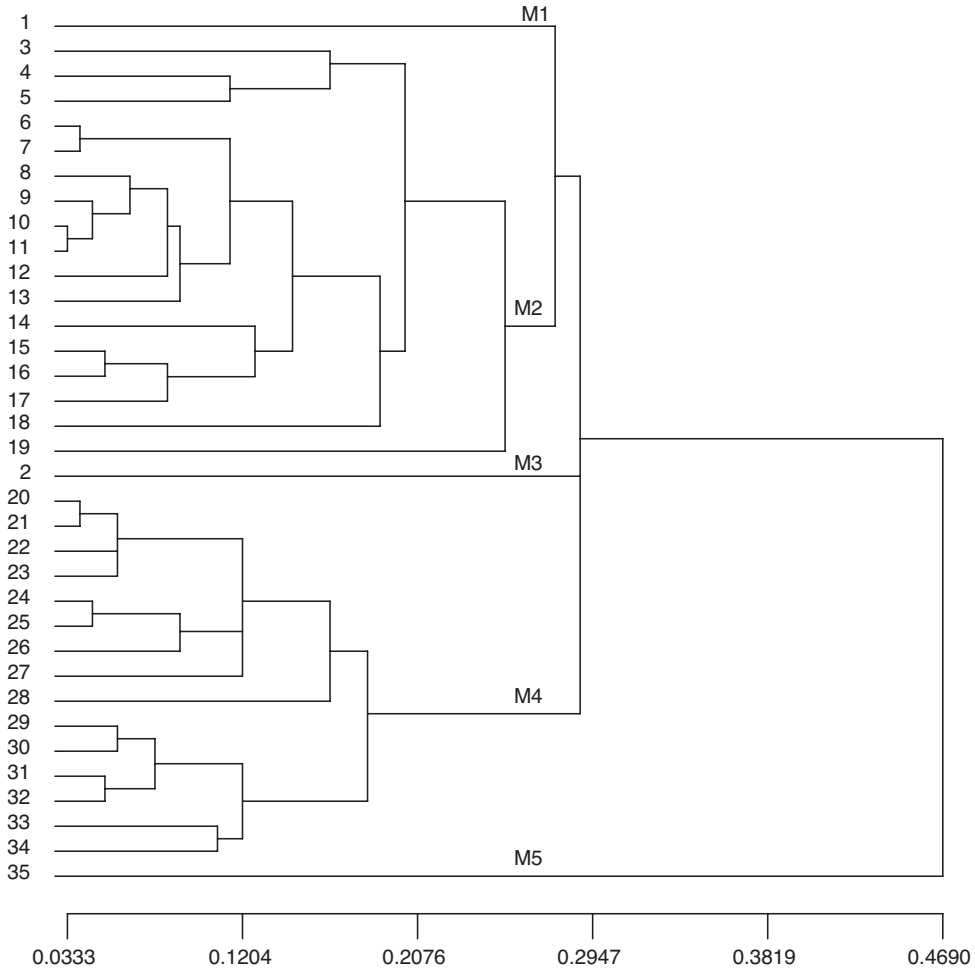

Fig. 2. Cluster analysis (MM, UPGMA), showing classification of Crowea exalata populations based on combined leaf and flower morphology data.

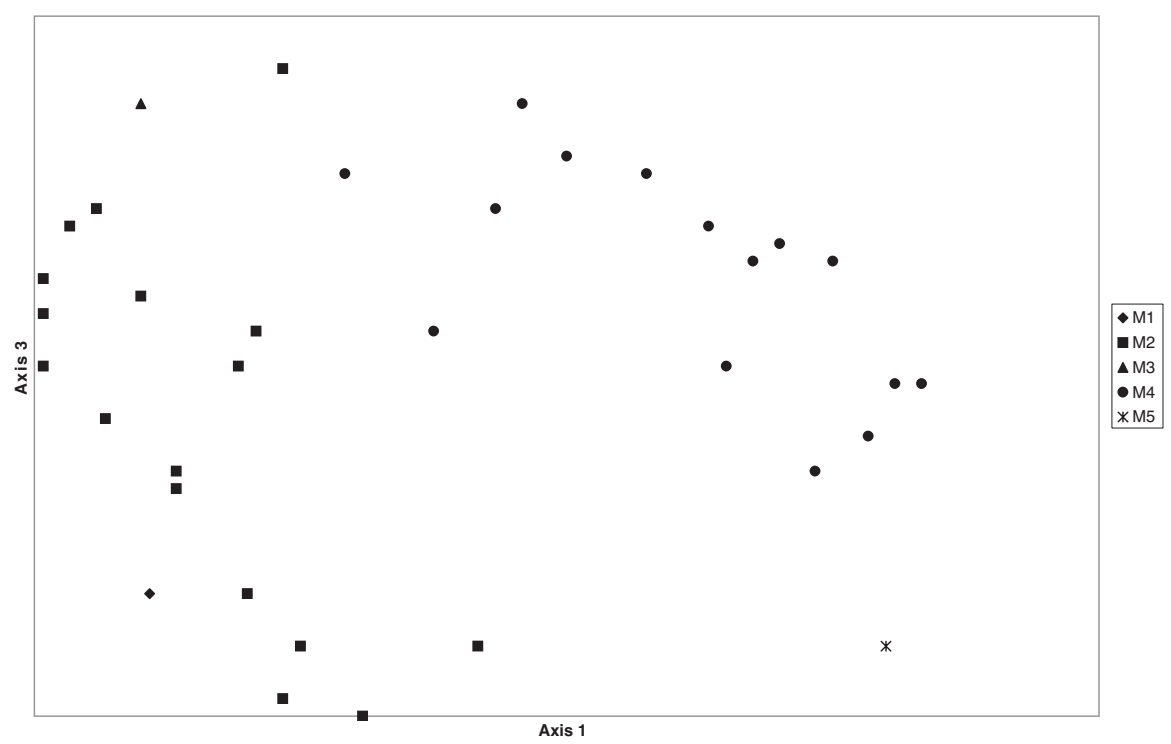

Fig. 3. Ordination (MM, PCoA) based on combined floral and leaf morphology data. Axis 1 accounts for $35 \%$ of the variation, and axis 3 accounts for $9 \%$. 
Group V3 contains two subgroups, all of which are from the South Coast of New South Wales, except for population 18 which is from the Snowfields of Victoria; Group V3.1 contains population 3, 18 and one individual from population 34; Group V3.2 has populations 4, 6, 33, and the remaining individuals from population 34. Group V3 was found to contain high amounts of croweacin and exalatacin (Table 3).

Table 3. Tentative identification of major volatile oil compounds (percent composition) found in samples used in this study; identifications based on Brophy et al. (1997).

Volatile Oil

$\begin{array}{llllll}\begin{array}{l}\text { Group \& pop'n } \\ \text { (voucher) }\end{array} & \text { croweacin } & \begin{array}{l}\text { (E)-methyl } \\ \text { isoeugenol }\end{array} & \text { (E)-carpacin } & \text { asaricin } & \text { exalatacin } \\ \text { Group V1 } & & & & & \\ \text { 10 (WG80 } & 4.1-24, & & & 58-71 & \\ \text { WG86, WG88) } & & & & & \\ 15 & 0.07-1.1 & 0.02-0.28 & 0.02-0.37 & 29-88 & \\ 19 & 0.01-0.04 & 0.3-0.75 & 0.1-1.0 & 0.07-0.2 & 0.02-0.07 \\ 21,22 & & & & 3.9-6.5 & \\ 24 & 0.32 & 0.56 & 0.02-0.03 & 39-96 & \\ \text { Group V2 } & & & & & \\ 1 & 0.03-0.1 & 0.36-1.4 & 0.16-0.7 & 1.8-3.4 & 0.09 \\ 10 \text { (WG82, WG85) } & 1.9-2.4 & & 0.04-0.05 & 0.25-1.0 & 0.1-0.25 \\ 11 & 0.08-0.58 & 0.08-0.32 & 20-44 & 0.15-1.4 & 0.06 \\ 13,14 & 0.01-0.07 & 0.16-0.32 & 20-83 & 0.02-0.4 & 0.05-0.11 \\ 20 & 0.03 & 29-40 & 38-44 & 0.1-0.14 & 0.02-0.08 \\ \text { Group V3 } & & & & & \\ 3 & 66-90 & 0.03 & 0.02 & 0.01-0.3 & 8.1 \\ 4 & 2-13.35 & 0.09-0.42 & 0.09-0.13 & 0.07-0.1 & 63-81 \\ 6 & 2.5-16.5 & 0.1 & 0.08-0.13 & 0.25-0.4 & 68-75 \\ 18 & 44-70 & 0.03-0.07 & 0.03-0.05 & 0.2-0.44 & 16-43 \\ 33 & 18-21 & 0.06-0.2 & 0.06-0.07 & 0.14-0.2 & 63-71 \\ 34 & 2.4-55 & 0.05-0.4 & 0.04-0.1 & 0.1-0.54 & 23-77\end{array}$

\section{Discussion}

In this study four taxonomic groups are recognised through numerical analysis of morphological (Figs 2, 3) and chemical flavonoid (Figs 4, 5) characters. The groups based on the morphological analysis (viz. Groups M1-M4) are discussed below. Groups M1-M4 are distinguishable on morphological characters, with chemical characters supporting the groups to a lesser extent. These groups are recognised here as subspecies, following the treatment of Wilson (1997). The placement of Group M5 is problematic (see discussion below).

Group 1 of both the morphological (M1; Figs 2, 3) and flavonoid analyses (F1; Figs 4, 5 ) is the population from the Whipstick State Forest (population 1), near Bendigo, in the Victorian Midlands (Fig. 1). It also formed a discrete group (V2.3) in the analysis 


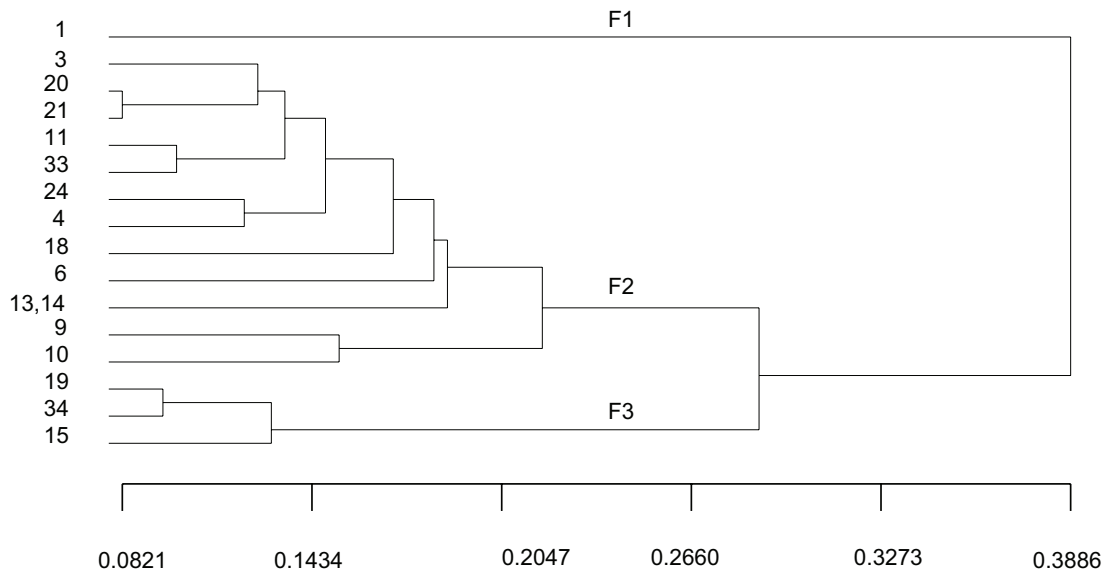

Fig. 4. Cluster analysis (MM, UPGMA), showing classification of Crowea exalata populations based on flavonoid data.

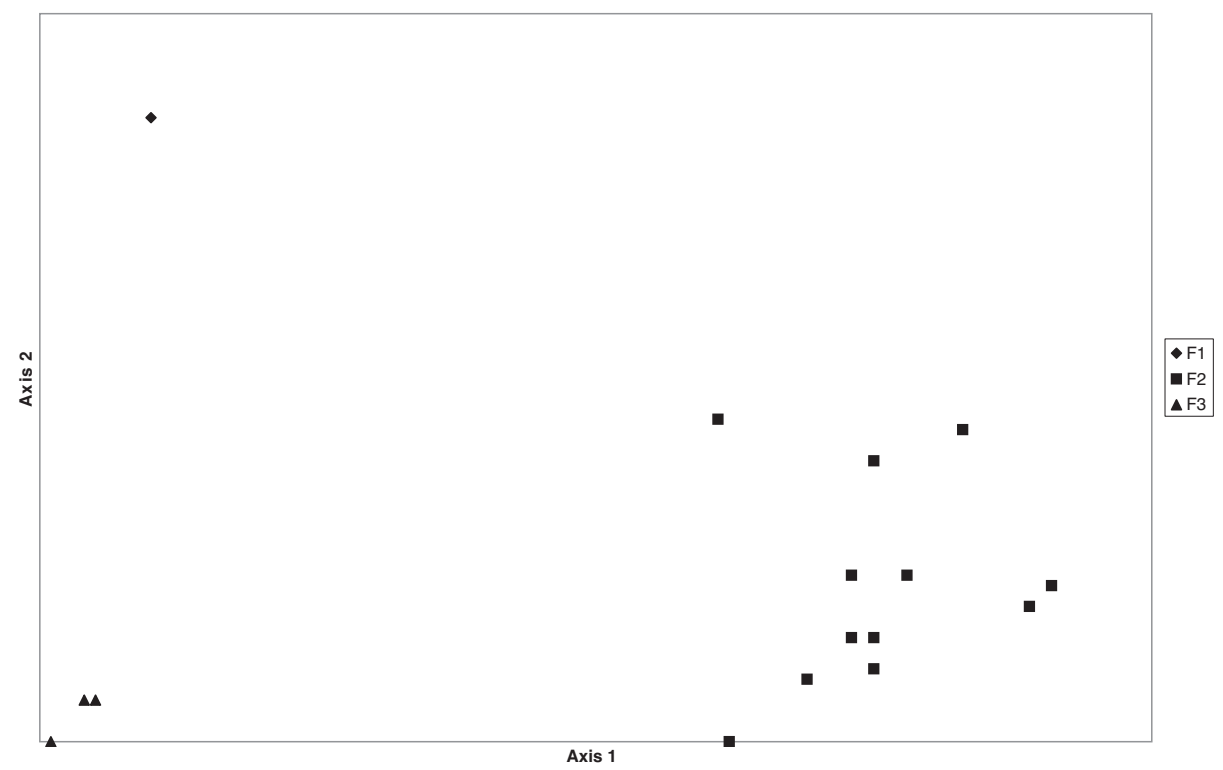

Fig. 5. Ordination (MM, PCoA) based on flavonoid data. Axis 1 accounts for $26 \%$ of the variation, and axis 2 accounts for $16 \%$. 
of the volatile oil data. The characters separating Group M1 from the remaining groups are characters 2 (leaf width), 3 (distance to widest point from the base), 8 (petal length) and a revolute leaf margin (not scored). Group M1 can also be separated from Groups M3 and M4 by characters 1 (leaf length) and 6 (perimeter of leaf). Group M1 has the shortest petal length of this species, range of $5-8.5 \mathrm{~mm}$ with an average of $7 \mathrm{~mm}$ (char. 8 ), compared with other populations which range from $8-12 \mathrm{~mm}$ with an average of $9.5 \mathrm{~mm}$. This group has four unique flavonoids and corresponds with C. exalata subsp. revoluta as described by Wilson (1997).

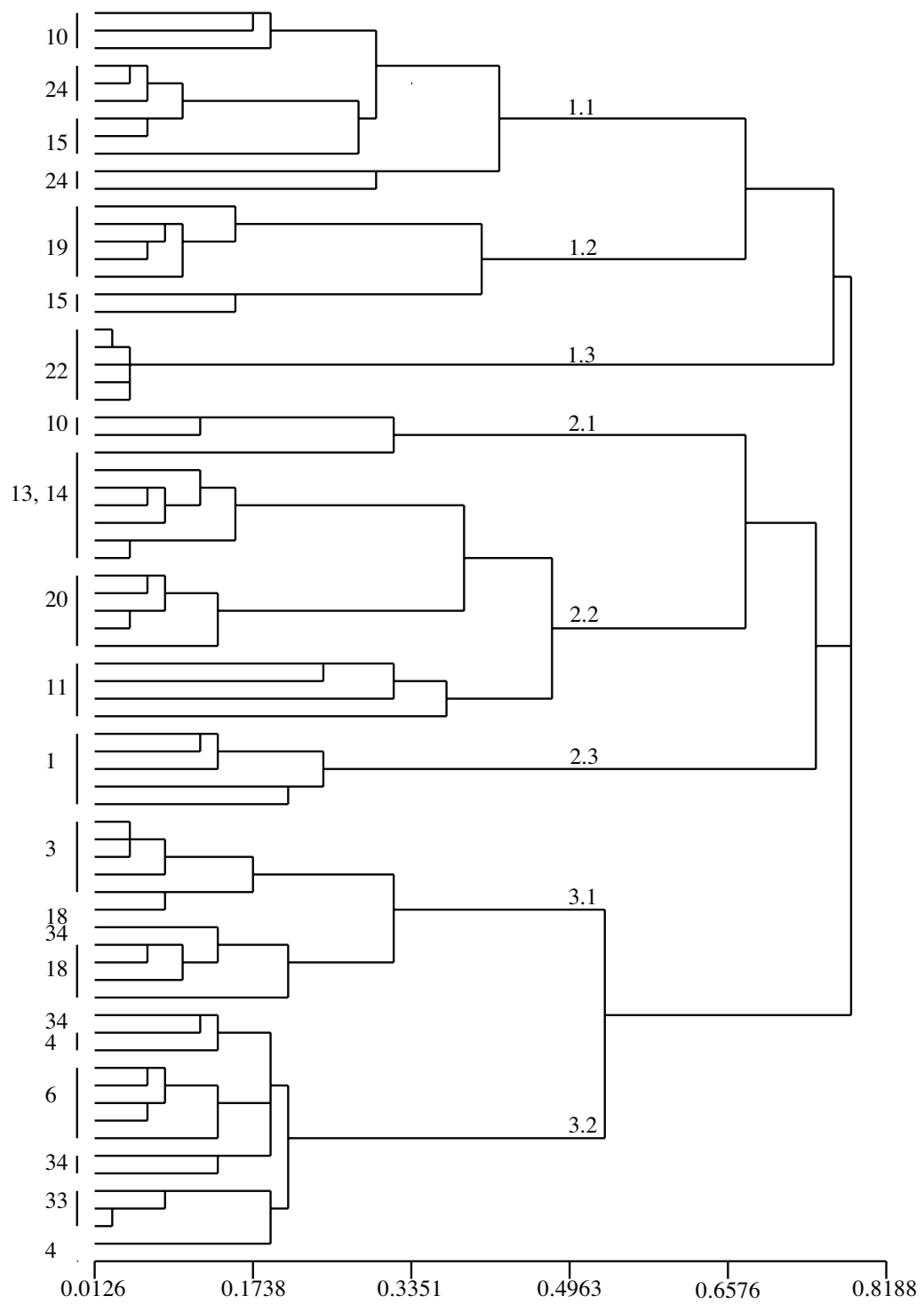

Fig. 6. Cluster analysis (MM, WPGMA), showing classification of Crowea exalata populations based on volatile oils data. 
Group M2 contains populations 3-19 which are found in the Snowfields, Eastern Highlands, East Gippsland and the northeastern corner of the Midlands in Victoria and in the South Coast, Central Coast, Central and North Western Slopes and the Central Tablelands of New South Wales (Fig. 1). This group is separated from Group M3 by characters 1 (leaf length), 3 (distance to widest point from the base), 4 (leaf length:leaf width), and 6 (perimeter of leaf), and from Group M4 by characters 6 and 7 (area of leaf). The lectotype of C. exalata, which was not scored for the analysis because there was insufficient material, is from Mitta Mitta (see Wilson 1970, 1997) and matches this group: therefore, this group is C. exalata subsp. exalata.

Group M3 is the population from Boyd Plateau (population 2), Central Tablelands of New South Wales (Fig. 1). This group is distinguishable from Group M4 by characters 1 (leaf length), 3 (distance to widest point from the base), 5 (distance to widest point from the base:leaf length), and 7 (area of leaf). The obcordate leaf shape (not scored but reflected well in character five.) of this group is also a very good character that separates it from all other groups. The group was not sampled for either the flavonoid or volatile oil studies because of confusion with herbarium labels and so it could not be located in the field when field work was carried out. Wilson had not seen any material of this taxon when he completed his 1997 treatment. This group is newly described below as C. exalata subsp. obcordata Gebert.

Group M4 contains populations 20-35 from the South Coast, Central Coast, and the North Western Slopes of New South Wales and from the Leichhardt and Moreton Districts of Queensland (Fig. 1). This group is separated from Groups M1 and M3 by characters 1, 2, 3, 6 and 7 (see above and the key to subspecies below). This group is newly described below as C. exalata subsp. magnifolia Gebert.

Group M5 proved to be problematic in the morphological analysis (Figs 2, 3) by being a distinct group. It is made up of a single herbarium specimen found on the south coast of New South Wales. The region in which the specimen was collected was visited on several occasions to try to locate the population but to no avail. Group M5 is very similar to Group M4, and found within the geographic range of that group, but has slightly larger leaves and flowers (possibly a polyploid). In the ordination of the morphological data (Fig. 3), Group M5 clusters close to populations of Group M4. With this in mind Group M5 is considered to belong to the same taxon as Group M4, described below as C. exalata subsp. magnifolia.

Through this study it was found that the usefulness of flavonoids in the separation of taxa within C. exalata was limited. The flavonoid analysis (Figs 4, 5) shows that Group F1 (= M1), C. exalata subsp. revoluta, from the Victorian Midlands (population 1) can be readily distinguished from all other groups by having four unique flavonoids (see above). The remaining groups were not clearly defined by flavonoid composition. If an assumption can be made that the degree of flavonoid divergence is proportional to time since taxonomic divergence (a micromolecular clock), then these results suggests that C. exalata subsp. revoluta has been isolated from the other subspecies for the longest period of time. There was no evidence of a grade between this subspecies and C. exalata subsp. exalata.

Analysis of the volatile oils provided three major groups (V1-V3) and shows that the individuals in each population are chemically very similar. This is particularly noticeable in population 22 (Fig. 6) and could indicate a high level of interbreeding within each population. It was noted during field work that populations of C. exalata were usually 
small and isolated from other populations. In only one population (population 10) were two groups of individuals defined in the volatile oil analysis (V1, V2), suggesting that two chemotypes are present within this population. Of the three major groups, only in V3 were the populations geographically close, all of these, except population 9, are found on the South Coast of New South Wales between Moruya and Imlay Creek.

These findings are supported, to an extent, by the results published by Brophy et al. (1997). Brophy et al. (1997) described the essential oils of Crowea species and outlined five chemotypes for C. exalata. Although the sampling by Brophy et al. (1997) was mainly confined to Queensland and a few populations in New South Wales and the present study to New South Wales and Victoria, three of the chemotypes described by Brophy et al. (1997) correspond with the groups found here (Table 3). These are chemotypes two, four, and five. Chemotype two of Brophy et al. corresponds with Group V2, chemotype four of Brophy et al. with Group V1 and chemotype five of Brophy et al. with Group V3 (Table 3). This is no coincidence as four of the populations $(24,20,34$ and 6) sampled in this study were populations studied by Brophy et al. (1997). It was not possible to allocate the two remaining chemotypes of Brophy et al. to groups in this study as several locations in northern New South Wales and southeastern Queensland were not sampled.

\section{Taxonomy}

Crowea exalata F.Muell., Trans. Philos. Soc. Victoria 1: 11 (1855)

Type: Victoria: Eastern Highlands: Mitta Mitta River, F. Mueller, Feb 1854. Lectotype (fide Wilson, Nuytsia 1: 18 (1970)), MEL4410.

Shrub to $2 \mathrm{~m}$ high. Branchlets glandular, obtusely angular to subterete, puberulous in sunken lines between rounded ridges. Leaves sessile, entire, narrow-oblong to narrowelliptic, rarely spathulate or obcordate, gradually narrowing to an attenuate base, 9-75 $\mathrm{mm}$ long, 1.5-9.5 mm wide, glabrous; apex acute to obtuse, mucronate to apiculate, rarely retuse or emarginate; lamina smooth, flat or with recurved margins, mid-vein slightly raised below. Flowers solitary, terminal to a short axillary shoot bearing few sub-apical leaves or shoot reduced to a short peduncle (to $1 \mathrm{~mm}$ long) with 2-5 small bracts; pedicel 1-4 mm long, sparsely puberulous. Calyx tube hemispherical; sepals imbricate, sub-orbicular to broad ovate, 2-2.5 $\mathrm{mm}$ long, puberulous to glabrous, ciliolate. Petals imbricate, thin, becoming chartaceous and broader in fruit, narrow- to broad-obovate, 5-14.5 $\mathrm{mm}$ long, 3-7 $\mathrm{mm}$ wide, white to pale mauve, turning reddish green with fruit, persistent. Stamens with sterile apices eventually spreading; filaments flattened, 2.5-3 mm long, pilose on the margins; anthers c. $1 \mathrm{~mm}$ long, appendage c. $2 \mathrm{~mm}$ long. Disc flat, forming a narrow lobed margin around ovary, dark green. Style short, thick, $0.5 \mathrm{~mm}$ long, pilose; stigma globular, c. $0.5 \mathrm{~mm}$ wide. Cocci glabrous, c. $7 \mathrm{~mm}$ long. Seed ovoid-reniform, 3.8-4 mm long; sclerotesta rugose, dull, dark brown to black. (Fig. 7)

Distribution and Ecology: Crowea exalata is a widespread species found in southeastern Queensland, down the ranges and near coastal areas of New South Wales through eastern Victoria to the Bendigo area. The species is found in coastal to montane environments usually on well-drained soils or in rocky places in heath or Eucalyptus woodland. The inland populations are often found on clay-ironstone soils in boxironbark woodlands. 

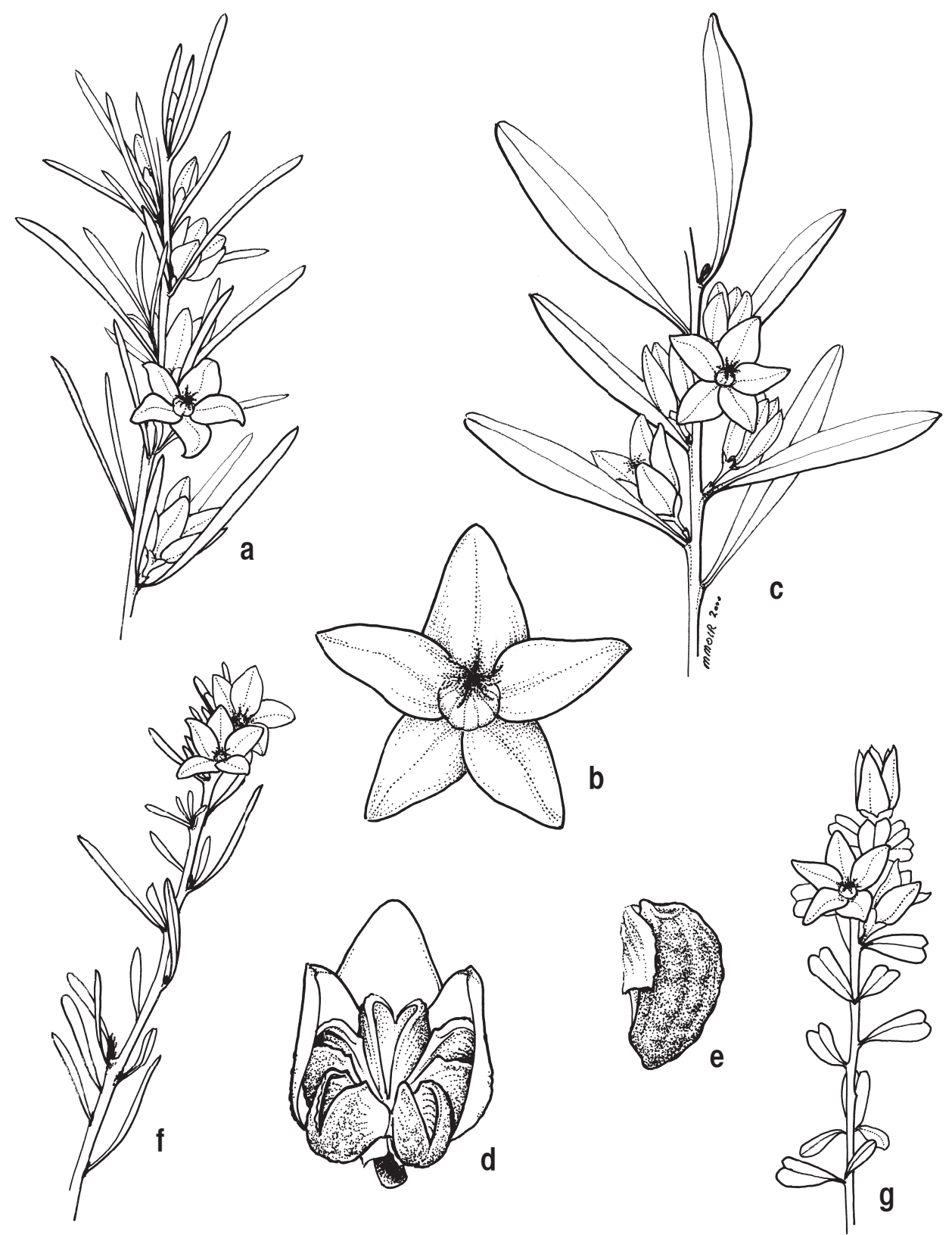

Fig. 7. a-g, Crowea exalata. a-b, subsp. exalata: a, flowering branchlet, $\times 1$ (James 479, NSW); b, flower, $\times 3$ (Gebert 20, MEL 2052865); c-e, subsp. magnifolia: c, flowering branchlet $\times 1$, (holotype: Grimshaw G601, BRI AQ600852); d, mature fruit, perianth and stamens removed, $\times 3$; e, seed, $\times 6$ (d-e, Gebert 48, LTB); f, subsp. revoluta, flowering branchlet, $\times 1$ (Duretto 627, MEL 2042763); g, subsp. obcordata, flowering branchlet, $\times 1$ (holotype: Olson 3997, NSW 257535). Drawn by Mali Moir. 


\section{Key to subspecies}

1 Leaves obcordate, leaf length less than or equal to twice the leaf width, 9-11 mm long (NSW, Central Tablelands) 4. subsp. obcordata

$1^{*}$ Leaves narrow oblong to narrow elliptic, leaf length greater than three times the leaf width, 10-75 mm long (Vic., NSW, Qld) 2

2 Leaf lamina 13-23 mm long, 1.5-2.5 mm wide, margin revolute (Bendigo region, central Vic.) 3. subsp. revoluta

$2^{\star}$ Leaf lamina 10-75 mm long, 1.5-9.5 mm wide, margin flat to slightly recurved (Vic., NSW, Qld) 3

3 Leaves narrow-oblong to oblanceolate, sometimes narrowly elliptic or spathulate, $10-60 \mathrm{~mm}$ long, 1.5-6 mm wide, tip obtuse to acute (Vic., NSW) 1. subsp. exalata

$3^{*}$ Leaves narrow-elliptic, rarely narrow-oblong to oblanceolate, 20-75 mm long, 3-9.5 mm wide, tip mucronate to apiculate, rarely acute or obtuse to retuse (southern populations) (NSW, Qld)

2. subsp. magnifolia

\section{Crowea exalata F.Muell. subsp. exalata}

Illustrations: Duretto, Flora of Victoria 4: 180, Fig. 33a (1999); Weston \& Harden, Flora of New South Wales 2, 2nd edn: 300 (2002).

Leaves narrow-oblong to oblanceolate, sometimes narrowly elliptic or spathulate, 10 $60 \mathrm{~mm}$ long, 1.5-6 mm wide, margins flat to slightly recurved, tip obtuse to acute. Pedicel 1-4 mm long. Petals 7-14.5 mm long, 3-7 mm wide. (Fig. 7a, b)

Notes: leaf shape varies considerably within this taxon, from short and narrow to short and wide to long and narrow. Several populations near the Wellington River and Dinner Creek Gorge in the Victorian Eastern Highlands have a unique spathulate leaf that, when crushed, has a sarsaparilla scent, stronger than usual. This subspecies can be difficult to separate from subsp. magnifolia between Sydney and Eden (NSW), where the subspecies are broadly sympatric. Further work is required to determine if these subspecies are ecologically distinct or if there is a cline involved. It may be the case that some plants in this area will not be able to be determined to subspecies which is justification for using the rank of subspecies.

Distribution and Ecology: Crowea exalata subsp. exalata is found south from Sydney, New South Wales, and in eastern Victoria. The habitats it occupies vary from steep gorges, sandy capes, and alpine regions to rocky escarpments, usually where the soil is moist but well drained. Flowering (November) December-March (-July).

Conservation status: this subspecies is widespread, well represented in conservation reserves and does not appear to be under immediate threat.

Selected specimens examined: New South Wales: Central Western Slopes: Buddigower State Forest, c. $4.25 \mathrm{~km}$ E from Alleena train crossing on Newell Highway $34^{\circ} 03^{\prime} \mathrm{S} 147^{\circ} 05^{\prime} \mathrm{E}$, Gebert 70-79 \& Mole, 19 Sep 1998 (WG 70, 71, 73, 75, 78 - LTB, MEL; WG72 - MEL; WG 74, 76, 77, 79 - LTB); 2.25 km NNE Buggajool Trig., 3409'S 147²12'E, Gebert 80-89 \& Mole, 19 Sep 1998 (WG80 - LTB, MEL, NSW; WG81-89 - LTB). Central Coast: Glenbrook 3346'S 150³7'E, Constable s.n., 13 Nov 1957 (NSW). Southern Tablelands: Ginninderra Falls, lower falls, $200 \mathrm{~m}$ upstream from Murrumbidgee River 35¹1'S 148 $56^{\prime} \mathrm{E}$, Taws 394, 27 Jun 1994 (MEL, NSW). South Coast: Bournda Trig Point, Bournda National Park 36² $48^{\prime}$ S 149 $54^{\prime}$ E, Gebert 11-20 \& 
Duretto, 27 Aug 1998 (WG11-12, 15-20 - LTB; WG13 - LTB, MEL, NSW; WG14 - LTB, NSW); Jingera Rock, Egan Peaks Nature Reserve 36 59'S 14940'E, Albrecht 2689, 18 Jul 1986 (MEL); $900 \mathrm{~m}$ from lighthouse entrance, Green Cape $37^{\circ} 15^{\prime} \mathrm{S} 150^{\circ} 2^{\prime} \mathrm{E}$, Gebert 21-30 \& Duretto, 27 Aug 1998 (WG21, 22, 24, 25, 27-30 - LTB; WG23 - LTB, NSW, MEL; WG26 - LTB, MEL); Imlay Creek

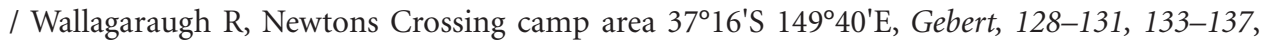
1 Dec 1998 (WG128 - MEL; WG129-131, 133-137 - LTB). Victoria: East Gippsland: Nowa Nowa. 37²4'S 14805'E, Gebert 31-33, 29 Aug 1998 (MEL). Eastern Highlands: Pine Mountain, Burrowa-Pine Mt National Park. 3601'S 14750'E, Gebert, 90-99 \& Mole, 20 Sep 1998 (WG90, 92-99 - LTB; WG91 - LTB, MEL); Beside Doldorook Track spur, S of Doldorook track junction with Ben Cruachan Ck, 37²4'S 146²4'E, Gebert 148-167 \& Mole, 22 Dec 1998 (WG148-150, 152-158, 160-167 - LTB; WG151, 159 - MEL); Valleys of the Upper Macalister River $37^{\circ} 48^{\prime} \mathrm{S}$ $146^{\circ} 40^{\prime} \mathrm{E}$, Mueller, Mar 1861 (MEL); MacAlister River, 1st crossing on Back Soil Gully track, N of Glencairn 37²28'S 146³3'E, Gebert 178-179, 29 Dec 1998 (WG178 - LTB, MEL, NSW; WG179 - LTB, MEL); Bruntons Bridge, Thompson River 3800'S 146²8'E, Gebert, 117-126, 6 Nov 1998 (WG117-120, 123-126 - LTB; WG121-122 - LTB, MEL). Snowfields: Mt Wellington 37³0'S $146^{\circ} 51^{\prime} \mathrm{E}$, Littlejohn s.n., 10 Jan 1940 (MEL); saddle between Vallejo Ganther Hut and Mt Howitt on walking track 37010'S 146²0'E, Gebert 190-199, 31 Dec 1998 (WG190-198 - LTB; WG199 - LTB, MEL) ); Crosscut Saw between Mts Howitt and Speculation, $2.3 \mathrm{~km}$ due north from Mt Howitt 379'S 146 38'E, Walsh 2547, 7 Jan 1981 (CANB, MEL); Dandongadale Falls, east of Mt Cobbler 3703'S 146³7'E, Muir 735, 29 Mar 1959 (MEL); Dinner Creek Gorge, beside Bennison Plains Road, $13.6 \mathrm{~km}$ direct NNE from Licola 37³0'S 146²0'E, Walsh 1799, 19 Oct 1987 (CANB, MEL, NSW); Dinner Creek Gorge 37³1'S 146²40'E, Gebert 180-189, 29 Dec 1998 (WG180-186, 188, 189 - MEL; WG187 - MEL, NSW); Third crossing of Wellington River on walking track to Lake Tarli [=Tali] Karng 37³1'S 146³9'E, Gebert 168-177 \& Mole, 22 Dec 1998 (WG168, 173 LTB, MEL; WG169-172, 174-177 - LTB).

\section{Crowea exalata subsp. magnifolia Gebert, subsp. nov.}

A subspecie typica foliis anguste ellipticis $20-75 \mathrm{~mm}$ longis, $3-9.5 \mathrm{~mm}$ latis, apicibus mucronatis vel apiculatis differt.

Type: Queensland: Moreton District: immediately below summit of Mt Byron, Mt Mee State Forest, $27^{\circ} 06^{\prime} \mathrm{S} 152^{\circ} 40^{\prime} \mathrm{E}$, Grimshaw G601 and Figg, 11 Apr 1994. Holotype: BRI AQ600852, transparencies MEL2172084.

[Crowea saligna auct. non Andrews: sensu EM Ross in TD Stanley and EM Ross, Flora of South East Queensland 1: 646 (1983)]

Illustration: Weston \& Harden, Flora of New South Wales 2, 2nd edn: 300 (2002).

Leaves narrow elliptic, rarely narrow oblong to oblanceolate, $20-75 \mathrm{~mm}$ long, 3-9.5 mm wide, margins flat to slightly recurved, tip mucronate to apiculate, rarely acute or obtuse to retuse (southern populations). Pedicel 1.5-4 mm long. Petals 7.5-14 mm long, 3.5-7 mm wide. (Fig. $7 \mathrm{c}-\mathrm{e}$ )

Notes: Crowea exalata subsp. magnifolia has large and distinct oil glands on the abaxial surface of the leaves which are more apparent than those of the other subspecies. Leaves of most populations have a strong aniseed or sarsaparilla scent. This subspecies and the typical subspecies can be difficult to separate in populations between Sydney and Eden (NSW).

Distribution and Ecology: this subspecies is found from the South Coast of New South Wales north to south-eastern Queensland. It is found in moist but well drained soils. Flowering mainly October-April. 
Conservation status: Crowea exalata subsp. magnifolia is widespread and well represented in conservation reserves (eg. Deua N.P., Mt Kaputar N.P., Expedition N.P.). It does not appear to be under immediate threat.

Etymology: the subspecific epithet is derived from Latin, magnus (large) and folium (leaf), and refers to the large size of the leaves, as compared to the other subspecies.

Selected specimens examined: Queensland: Leichhardt: Robinson Gorge, Expedition Range National Park 2517'41"S 149¹0'32"E, Forster 17742 \& Figg, 17 Sep 1995 (MEL, NSW). Moreton: Dianas Bath, D’Aguilar Range near Mount Byron 2706'S 152 40'E, Forster 16398, 4 Apr 1995 (MEL, NSW); State Forest 893, Mount Mee 2706'54"S 15241'28"E, Forster 17392, 4 Aug 1995 (MEL, NSW); Immediately below summit of Mt Byron, Mt Mee State Forest $27^{\circ} 07^{\prime} \mathrm{S} 152^{\circ} 40^{\prime} \mathrm{E}$, Grimshaw 601 \& Figg, 11 Apr 1994 (MEL). New South Wales: Northern Tablelands: Tributary of Flagstone Creek 29¹7'S 1513'ㄹ, Gebert 34-43 \& Mole, 14 Sep 1998 (WG34 - LTB, MEL, NSW, UNE; WG35-43 - LTB); $4 \mathrm{~km}$ east of Howell on Tingha road 29 $57^{\prime} \mathrm{S} 151^{\circ} 05^{\prime} \mathrm{E}$, Forster $16406 \mathrm{~d}$ Machin, 21 Apr 1995 (MEL, NSW); Howell area, 50m E of Howell-Copeton Dam road, c. 50m N of Quart Pot Creek 29 $56^{\prime} \mathrm{S} 151^{\circ} 02^{\prime} \mathrm{E}$, Copeland 2756, 22 Nov 2000 (BRI, MEL, NSW); On roadside heading towards old mine which is $900 \mathrm{~m} \mathrm{SE}$ of Howell $29^{\circ} 57^{\prime} \mathrm{S} 151^{\circ} 02^{\prime} \mathrm{E}$, Gebert 46 \& Mole, 14 Sep 1998 (MEL); Waa Gorge, walking track on N side of Gorge, above Mill-Bullah water hole, Mt Kaputar National Park 3004'S 15006'E, Gebert 48-57 \& Mole, 16 Sep 1998 (WG 48-53, 55-57 - LTB; WG54 - LTB, MEL, NSW, UNE); Top of Waa Gorge, Mt Kaputar National Park $30^{\circ} 04^{\prime} \mathrm{S} 150^{\circ} 06^{\prime} \mathrm{E}$, Gebert 58-67, \& Mole, 16 Sep 1998 (MEL); Yalwal 34 55'S 150²2'E, Blaxell 1605, 11 Apr 1978 (NSW). Central Coast: Tahmoor, Stratford Rd (end) adjacent to Bargo River, 341ㄴ'S 150³5'E, Gebert 100-109, 14 Oct 1998 (WG100 - LTB, MEL; WG101-109 - LTB). South Coast: Yalwal 3455'S 150²4'E, Gebert 127, 24 Nov 1998 (MEL); $1 \mathrm{~km} \mathrm{~N}$ of Coondella Trig, Deua National Park 35 56'S 14954'E, Gebert 138-147 \& Pearson, 2 Dec 1998 (WG138, 141, 144 - LTB, MEL; WG139, 140, 142, 143, 145-147 - LTB); Dr George Mountain 36²40'S 14954'E, Gebert 110-116, 15 Oct 1998 (WG110, 116 - LTB, MEL; WG111-115 - LTB); Nethercote Falls, Yowaka River, Nullica State Forest 3659'S 149²49'E, Albrecht 2290, 13 Dec 1985 (MEL).

3. Crowea exalata subsp. revoluta Paul G.Wilson, Nuytsia 11: 430 (1997)

Type: Victoria: Midlands: 1 mile [1.6km] north of Lightning Hill near Eaglehawk, D.L. Paton, 18 Dec 1916. Holotype: MEL4413. Isotypes: MEL4414, MEL4415, MEL4416, MEL4417, MEL4418.

Leaves narrow oblong, 13-23 mm long, 1.5-2.5 mm wide, margins revolute, tip acute rarely apiculate. Pedicel $0.5-1.5 \mathrm{~mm}$ long. Petals $5-8.5 \mathrm{~mm}$ long, 3-4.5 mm wide. (Fig. 7f)

Distribution and Ecology: Crowea exalata subsp. revoluta is confined to the Midlands region, central Victoria, between Bendigo and Kamarooka, and also near St Arnaud. Found on clay-ironstone soils in Box-Ironbark communities. Flowers sporadically throughout the year.

Conservation status: Walsh and Stajsic (2007) considered this taxon to be vulnerable. Although not widespread, this subspecies is common in several reserves (eg. Whipstick, Kamarooka) around Bendigo and does not appear to be under immediate threat.

Etymology: the subspecific epithet is derived from Latin, revolutus (revolute or rolled back), and alludes to the leaf margins being rolled under the leaf.

Selected specimens examined: Victoria: Midlands: Western Whipstick, 1 mile north of Blue

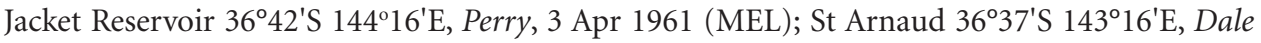
[ACB 3714], May 1951 (MEL); Reservoir on Lightning Hill Road [Bendigo], 36 $46^{\circ} \mathrm{S} 144^{\circ} 16^{\prime} \mathrm{E}$, 
Robbins [ACB 38646], 12 Jul 1947 (MEL); Gobarup Flora Reserve 36²4'S 14453'E, Beauglehole 68932, 4 May 1981 (MEL); Kamarooka State Park 36³1'S 144²3'E, Beauglehole 69683, 2 Nov 1981 (MEL); Trail to Flagstaff Hill, 17 km NW of Bendigo, Whipstick State Park. 36 $38^{\circ} \mathrm{S}$ $144^{\circ} 15^{\prime} \mathrm{E}$, Jobson 3272, 16 Oct 1994 (MEL); Foxes Bend Road, Whipstick Scrub 36 $40^{\circ} \mathrm{S} 144^{\circ} 15^{\prime} \mathrm{E}$, Duretto 627 \& PG Neish, 1 Sep 1995 (MEL); Whipstick State Forest near Bendigo, 1km due N on Foxes Bend Rd from Whipstick Road 36 $41^{\prime}$ S 144 ${ }^{\circ} 17^{\prime} E$, Gebert 1-10 \& Whiffin, 11 Aug 1998 (WG1, 7 - LTB, MEL; WG2-6, 8-10 - LTB).

4. Crowea exalata subsp. obcordata Gebert, subsp. nov.

A subspecie typica follis obcordatis 9-11 mm longis, 4-5.5 mm latis differt.

Type: New South Wales: Central Tablelands: Budthingeroo Creek, 3355'S, 15001'E, I. Olson 3997, 12 Apr 1992. Holotype: NSW257535, transparencies MEL2172083. Isotype: MEL2026011.

Illustration: Weston \& Harden, Flora of New South Wales 2, 2nd edn: 300 (2002).

Leaves obcordate, 9-11 mm long, 4-5.5 mm wide, margins flat. Pedicel $3.5 \mathrm{~mm}$ long. Petals 7-9 mm long, $4.5 \mathrm{~mm}$ wide. (Fig. $7 \mathrm{~g}$ )

Notes: Crowea exalata subsp. obcordata can be distinguished from all the other subspecies by its small, obcordate leaves.

Distribution and Ecology: this subspecies is found on the Boyd Plateau, Central Tablelands, New South Wales, near creeks. Flowering material has been collected in April.

Conservation status: Crowea exalata subsp. obcordata is known only from the type collection from Kanangra-Boyd National Park and a conservation code, following the format of Briggs and Leigh (1996), of 2KC is appropriate for this subspecies. Surveys are required to ascertain the extent of the known population.

Etymology: the subspecific epithet refers to the obcordate shape of the leaves.

Specimens seen: known from the type material only.

\section{Acknowledgments}

We would like to thank the directors of BRI, CANB, MEL, NE and NSW for loan of specimens; the Department of Natural Resources and Environment, Victoria, and the National Parks and Wildlife Service and State Forests of New South Wales for collecting permits; Trevor Whiffin (Latrobe Uni.) for assistance with the project; Bryan Mole for field assistance; Neville Walsh for the Latin diagnoses; Mali Moir for the excellent line drawing featured in Figure 7 and Niels Klazenga for assistance with data analysis.

\section{References}

Andrews HC (1800) Botanists Repository-Volume Two. (Andrews: London)

Baillon H (1873) Histoire des Plante- Tome IV. (Hachette: Paris)

Banks JCG \& Hillis WE (1969) The characterisation of populations of Eucalyptus camaldulensis by chemical features. Australian Journal of Botany 17: 133-146. 
Bayly MJ, Brophy JJ, Forster PI, Goldsack RJ \& Wilson PG (1998) Reinstatement of Eriostemon banksii (Rutaceae), with a report on the composition of leaf essential oils in E. banksii and $E$. australasius s. str. Australian Systematic Botany 11: 13-22.

Beadle NCW, Evans OD \& Carolin RC (1962) Handbook of the Vascular Plants of the Sydney District and Blue Mountains. (University of New England: Armidale)

Belbin L (1987) PATN: Pattern analysis package. Users, Example, Command and Reference Manuals. (CSIRO Australia, Division of Wildlife and Ecology: Canberra)

Bentham G (1863) Flora Australiensis, vol. 1. (Lovell Reeve \& Co.: London)

Briggs JD \& Leigh JH (1996) Rare or Threatened Australian Plants. Revised edn. (CSIRO Australia: Collingwood)

Brooker MIH \& Lassak EV (1981) The volatile oils of Eucalyptus ovata Labill. and E. brookeriana A. M. Gray (Myrtaceae). Australian Journal of Botany 29: 605-615.

Brophy JJ, Goldsack RJ \& Punruckvong A (1997) Essential oils of the genus Crowea (Rutaceae). Journal of Essential Oil Research 9: 401-409.

Conn BJ \& Whiffin T (1987) A study of the variation within and between Prostanthera monticola and P. walteri (Labiatae) using leaf volatile oils. Mulleria 6: 375-382.

Duewell H (1997) Chemotaxonomy of the genus Xanthorrhoea. Biochemical Systematics and Ecology 25: 717-738.

Duretto MF (1999) Crowea. P. 177 in Walsh NG \& Entwisle TJ (eds) Flora of Victoria, vol. 2. (Inkata Press: Melbourne)

Dureto MF \& Ladiges PY (1997) Morphological variation within the Boronia grandisepala group (Rutaceae) and the desacription of nine taxa endemic to the Northern Territory, Australia. Australian Systematic Botany 10: 249-302.

Flake RH, Urbatsch L \& Turner BL (1978) Chemical documentation of allopatric introgression in Juniperus. Systematic Botany 3: 129-144.

Gebert WA (1999) A systematic study of Crowea exalata (Rutaceae) and the informal recognition of two new subspecies. (Unpublished Honours Thesis, School of Botany, La Trobe University)

Ghisalberti EL (1997) Phytochemistry of the Australian Rutaceae: Boronia, Eriostemon and Phebalium species. Phytochemistry 47: 163-176.

Hanover JW (1966) Genetics of terpenes. 1. Gene control of monoterpene levels in Pinus monticola Dougl. Heredity 21: 73-84.

Harborne JB \& Turner BL (1984) Plant Chemosystematics. (Academic Press: London)

Holmgren PK, Holmgren NH \& Barnett L (1990) Index Herbariorum. Part 1. The Herbarium of the World, 8th edn. (New York Botanical Gardens: New York)

Kottek MH, Ladiges PY \& Whiffin T (1990) A new species of stringybark, Eucalyptus mackintii, from eastern Victoria and it's phenetic and cladistic relationships. Australian Systematic Botany 3: 671-687.

Leach GJ \& Whiffin T (1978) Analysis of a hybrid swarm between Acacia brachybotrya and A. calamifolia (Leguminosae). Botanical Journal of the Linnean Society 76: 53-69.

Leach GJ \& Whiffin T (1989) Ontogenetic, seasonal and diurnal variation in leaf volatile oils and leaf phenolics of Angophora costata. Australian Systematic Botany 2: 99-111.

Mabry TJ, Markham KR \& Thomas MB (1970) The Systematic Identification of Flavonoids. (Springer-Verlag: New York)

Maiden JH \& Betche E (1916) A Census of New South Wales Plants. (Gullick, Government Printer: Sydney)

Markham KR (1982) Techniques of Flavonoid Identification. (Academic Press: London)

McClure JW \& Alston RE (1966) A chemotaxonomic study of Lemnaceae. American Journal of Botany 53: 849-860.

Meacham CA \& Duncan T (1989) Morphosys Manual. (University of California)

Middleton ND, Ladiges PY \& Enright NJ (1996) Population ecology of Banksia saxicola (Proteaceae). Proceedings of the Royal Society of Victoria 108: 43-56.

Moore C \& Betche E (1893) Handbook of the Flora of New South Wales. (Potter, Government Printer: Sydney) 
Mueller F (1862) Plants Indigenous to the Colony of Victoria, Vol. 1. (Government Printer: Melbourne)

Newnham MR, Ladiges PY \& Whiffin T (1986) Origin of the Grampians shining peppermint a new subspecies of Eucalyptus willisii Ladiges, Humphries \& Brooker. Australian Journal of Botany 34: 331-348.

Penfold AR \& Morrison FR (1922) The essential oil of Eriostemon crowei (Crowea saligna) and the presence of a new phenol ether. Journal and Proceedings of the Royal Society of New South Wales 56: 227-232.

Pimentel RA (1981) A comparative study of data and ordination techniques based on a hybrid swarm of sand verbenas (Abronia Juss.). Systematic Zoology 30: 250-267.

Raleigh RE, Ladiges PY, Entwisle TJ \& Drinnan AN (1994) Morphometric studies of the genus Tasmannia (Winteraceae) in Victoria, Australia. Muelleria 8: 235-256.

Rudloff E, von (1972) Seasonal variation in the composition of the volatile oil of the leaves, buds, and twigs of white spruce (Picea glauca). Canadian Journal of Botany 50: 1595-603.

Smith JE (1798) The characters of twenty new genera of plants. Transactions of the Linnean Society 4: 213-223.

Smith JE (1808) In Rees A, The cyclopedia: or, universal dictionary of arts, sciences and literature/ Abraham Rees, vol. 10. (Longman: London)

Sneath PHA \& Sokal RR (1973). Numerical Taxonomy. (WH Freeman \& Co.: San Francisco)

Southwell IA \& Brophy JJ (1992) Differentiation within the Australian Tasmannia by essential oil comparison. Phytochemistry 31: 3073-3081.

Walsh N.G. \& Stajsic V. (2007) A census of the vascular plants of Victoria. $8^{\text {th }}$ edition. (Royal Botanic Gardens Melbourne: Melbourne)

Whiffin T (1977) Volatile oils and the study of natural hybridisation between Correa aemula and C. reflexa (Rutaceae). Australian Journal of Botany 25: 291-298.

Whiffin T (1981) Analysis of hybridisation between Eucalyptus pauciflora Sieber ex Spreng. and E. radiata Sieber ex DC. (Myrtaceae). Botanical Journal of the Linnean Society 83: 237-250.

Whiffin T (1982a) Numerical analysis of volatile oil data in systematic studies of Australian rainforest trees. Taxon 31: 204-210.

Whiffin T (1982b) Variation and evolution in the genus Flindersia (Rutaceae). II Review of methods for geographic variation analysis of volatile oil data. Australian Journal of Botany 30: 645-657.

Whiffin T \& Bouchier A (1992) Chemical and morphological variation within a population of Eucalyptus radiata (Myrtaceae) exhibiting leaf volatile oil chemical forms. Australian Systematic Botany 5: 95-107.

Whiffin T \& Hyland B (1989) The extent and systematic significance of seasonal variation of volatile oil composition in Australian rainforest trees. Taxon 38: 167-177.

Whiffin T \& Ladiges PY (1992) Patterns of variation and relationships in the Eucalyptus alpina - E. baxteri complex (Myrtaceae) based on leaf volatile oils. Australian Systematic Botany 5: 695-709.

Wilson PG (1970) A taxonomic revision of the genera Crowea, Eriostemon and Phebalium (Rutaceae). Nuytsia 1: 5-155.

Wilson PG (1997) Brief notes on the genus Crowea (Rutaceae). Nuytsia 11: 429-430.

Wilson PG (1998) A taxonomic review of the genera Eriostemon and Philotheca (Rutaceae: Boronieae). Nuytsia 12: 239-265.

Wright IJ \& Ladiges PY (1997) Geographic variation in Eucalyptus diversifolia (Myrtaceae) and the recognition of new subspecies E. diversifolia subsp. hesperia and E. diversifolia subsp. megacarpa. Australian Systematic Botany 10: 651-680. 